\title{
Correlation of maternal age with birth weight: need to reemphasize
}

\author{
Suyash Goel*, Roshni Abichandani
}

Department of Obstetrics and Gynecology, AFMS Hospital, Roorkee, Haridwar, Uttarakhand, India

Received: 13 October 2019

Accepted: 19 November 2019

\section{*Correspondence: \\ Dr. Suyash Goel, \\ E-mail: palakgoe@gmail.com}

Copyright: () the author(s), publisher and licensee Medip Academy. This is an open-access article distributed under the terms of the Creative Commons Attribution Non-Commercial License, which permits unrestricted non-commercial use, distribution, and reproduction in any medium, provided the original work is properly cited.

\section{ABSTRACT}

Background: Women at both ends of the reproductive age spectrum have unique outcomes which needs to be considered. Adolescents are at increased risk for anaemia, preterm delivery, fetal growth restriction and preeclampsia. The maternal mortality rate is higher on extremes of the age. However, there is marked variability of the birth wt even with in the age group from 19-35 years of age. The present study was conducted with an objective to assess the correlation of Maternal age with birth weight.

Methods: A total of 135 women between age 19-35 years were considered who had delivered at term $(n=135)$ and women with any risk factors were excluded. Women were divided in three groups with age <25 years, 26-30 years and $>30$ years. Both primigravida and multigravida women were included without considering the mode of delivery.

Results: According to birth weight, 113 cases had their birth weight $>2.5 \mathrm{~kg}$ and out of them 43,56 and 14 cases belonged to age group $<25,26-30$ and $>30$ years respectively while only 22 cases had their birth weight $<2.5 \mathrm{~kg}$ and out of them 9, 8 and 5 cases had their age group $<25,26-30$ and $>30$ years. Mean birth weight in age group $<25$ years was $2.96 \pm 0.46 \mathrm{~kg}$, in age group 26-30 years, it was $3.19 \pm 0.47 \mathrm{~kg}$ and in age group $>30$ years it was $2.79 \pm 0.54$. On applying ANOVA test, the difference was found statistically significant $(\mathrm{p}<0.01)$.

Conclusions: The variation in birth weight with respect to maternal age is significant. Limitation of this study was group comprising of 135 women.

Keywords: Adolescent age, Insulin like growth factor, Low birth weight, Maternal age, Pre-eclampsia, Preterm delivery

\section{INTRODUCTION}

The impact of maternal age on obstetric and neonatal outcomes has been studied in various parts of the world and with variable results. Also, various factors like Insulin like growth factors, fetal leptin and various other adipokines affect fetal growth. ${ }^{1-6}$ A WHO multicounty study including 29 low-income and middle-income countries found adolescent mothers were at higher risk of several adverse outcomes including low birth weight, preterm delivery, eclampsia and infections compared with mothers aged 20-24 years. It has become evident that adolescent age, advance age, factors like smoking, alcohol, deprivation also affects the birth weight. ${ }^{7-12}$ Birth weight is a major determinant of child's health and nutrition. Adolescents are at increased risk for anaemia, preterm delivery, fetal growth restriction and preeclampsia. The maternal mortality rate is higher on extremes of the age. However, there is marked variability of the birth weight even with in the age group from 19-35 years of age. The present study was conducted with an objective to assess the correlation of Maternal age from 19-35 years with birth weight.

\section{METHODS}

The present observational study was conducted at one of the AFMS Hospitals where the average delivery rate per 
year is 350. A total of 135 women between age 19-35 years were considered who had delivered at term $(\mathrm{n}=$ 135 ) and women with any risk factors were excluded.

\section{Inclusion criteria}

- Age 19-35 years, primigravida and multigravida, spontaneous conception, caesarean/ normal vaginal delivery/ instrumental deliveries.

\section{Exclusion criteria}

Patients with following risk factors were excluded from the study

- Assisted reproduction, anemia, hypertensive disorder, diabetes, thrombophilia, rh negative iso-immunized, obesity, smokers, deprivation, history of IUGR in previous pregnancy, low socioeconomic status, patients with any other medical/surgical illness.
Women were divided in three groups with age $<25$ years, 26-30 years and $>30$ years. Study population comprised of wives of serving armed forces personnel irrespective of geographical distribution. Both Primigravida and multigravida women were included without considering the mode of delivery. Birth weight were recorded by standard electronic weighing machine soon after delivery.

\section{Statistical analysis}

ANOVA test was applied to obtain the results.

\section{RESULTS}

According to birth weight, 113 cases had their birth weight $>2.5 \mathrm{~kg}$ and out of them 43,56 and 14 cases belonged to age group <25, 26-30 and >30 years respectively while only 22 cases had their birth weight $<2.5 \mathrm{~kg}$ and out of them 9,8 and 5 cases had their age group <25, 26-30 and $>30$ years (Table 1 ).

Table 1: Distribution of cases according to birth weight $(\mathrm{kg})$ in relation to age group.

\begin{tabular}{|c|c|c|c|c|c|c|c|c|}
\hline \multirow{3}{*}{$\begin{array}{l}\text { Birth weight } \\
\text { group (kg) }\end{array}$} & \multicolumn{6}{|c|}{ Age group (years) } & \multirow{2}{*}{\multicolumn{2}{|c|}{ Total }} \\
\hline & \multicolumn{2}{|c|}{$\leq 25$} & \multicolumn{2}{|c|}{$26-30$} & \multicolumn{2}{|c|}{$>\mathbf{3 0}$} & & \\
\hline & No. & $\%$ & No. & $\%$ & No. & $\%$ & No. & $\%$ \\
\hline$\leq 2.5$ & 9 & 17.3 & 8 & 12.5 & 5 & 26.3 & 22 & 16.3 \\
\hline$>2.5$ & 43 & 82.7 & 56 & 87.5 & 14 & 73.7 & 113 & 83.7 \\
\hline Total & 52 & & 64 & & 19 & & 135 & \\
\hline Mean & 2.96 & & 3.19 & & 2.79 & & 3.04 & \\
\hline SD & 0.46 & & 0.47 & & 0.54 & & 0.50 & \\
\hline$f$ & 6.307 & & & & & & & \\
\hline $\mathrm{p}$ & 0.002 & & & & & & & \\
\hline
\end{tabular}

Mean birth weight in age group $<25$ years was $2.96 \pm 0.46$ $\mathrm{kg}$, in age group 26-30 years, it was $3.19 \pm 0.47 \mathrm{~kg}$ and in age group $>30$ years it was $2.79 \pm 0.54$ (Table 1). On applying ANOVA test, the difference was found statistically significant $(\mathrm{p}<0.01)$.

\section{DISCUSSION}

Fetal development is determined by maternal provision of substrate, placental transfer of these substrates, and fetal growth potential governed by the genome. However, the precise cellular and molecular mechanisms by which normal fetal growth ensues are incompletely understood. That said, there is considerable evidence that insulin and insulin-like growth factors, particularly insulin-like growth factor-I (IGF-I), have an important role in regulation of fetal growth and weight gain., ${ }^{1,2}$ These growth factors are produced by virtually all fetal organs and are potent stimulators of cell division and differentiation. Other hormones implicated in fetal growth have been identified in recent years, particularly hormones derived from adipose tissue. These hormones are known broadly as adipokines and include leptin, the protein product of the obesity gene. Fetal leptin concentrations increase during gestation, and they correlate with birthweight. ${ }^{3,4}$ This relationship, however, is controversial in growth-restricted fetuses. ${ }^{5,6}$ Other adipokines under investigation include adiponectin, ghrelin, follistatin, resistin, visfatin, vaspin, omentin-1, apelin, and chemerin. Data for these adipokines are often conflicting, and their roles in normal and disordered fetal growth are still being elucidated. Fetal growth is also dependent on an adequate supply of nutrients. Glucose transfer has been extensively studied during pregnancy. Both excessive and diminished maternal glucose availability affect fetal growth. Reducing maternal glucose levels may result in a lower birthweight. Still, growth-restricted neonates do not typically show pathologically low glucose concentrations in their cord blood (Pardi, 2006). Fetal-growth restriction in response to glucose deprivation generally results only after longterm severe maternal caloric deprivation.

The impact of maternal age on obstetric and neonatal outcomes has been studied in various parts of the world and with variable results. A WHO multicounty study 
including 29 low-income and middle-income countries found adolescent mothers were at higher risk of several adverse outcomes including low birth weight, preterm delivery eclampsia and infections compared with mothers aged 20-24 years. Birth weight is a major determinant of child's health and nutrition. Adolescents are at increased risk for anaemia, preterm delivery, Fetal growth restriction and preeclampsia. The maternal mortality rate is higher on extremes of the age. However, there is marked variability of the birth weight even with in the age group from 19-35 years of age.

A systematic review aiming to assess the relationship between early first childbirth and increased risk of poor pregnancy outcomes found that there was considerable evidence to suggest that very young maternal age and advanced maternal age has adverse fetal outcomes. ${ }^{7}$ It is suggested that young women who are still themselves growing may compete with the fetus for nutrients, which may in turn impair fetal growth and result in low birthweight babies or babies who are small for their gestational age. The review also found a moderately increased risk of anaemia, premature birth and neonatal mortality associated with young maternal age. Advanced maternal age (35+ years) has also previously been shown to be an independent risk factor for adverse maternal and neonatal outcomes. ${ }^{8}$ This suggests that women aged 20 34 years could reasonably be considered as the population less likely to suffer age-related pregnancy complications. Differences in outcomes have also been associated with demographic and behavioral characteristics. Lifestyle and sociodemographic factors such as smoking, alcohol use and deprivation have all been shown to contribute to less favorable birth outcomes. ${ }^{9-11}$ It is also established that adolescent mothers in high-income countries are at higher risk of exhibiting these characteristics. ${ }^{12}$

In this study, 113 cases had their birth weight $>2.5 \mathrm{~kg}$ and out of them 43, 56 and 14 cases belonged to age group $<25,26-30$ and $>30$ years respectively while only 22 cases had their birth weight $<2.5 \mathrm{~kg}$ and out of them 9,8 and 5 cases had their age group <25, 26-30 and $>30$ years. Mean birth weight in age group $<25$ years was $2.96 \pm 0.46 \mathrm{~kg}$, in age group 26-30 years, it was $3.19 \pm 0.47$ $\mathrm{kg}$ and in age group $>30$ years it was $2.79 \pm 0.54$. On applying ANOVA test, the difference was found statistically significant $(\mathrm{p}<0.01)$. It was also noticed that out of 113 deliveries with birth weight $>2.5 \mathrm{~kg}, 99$ deliveries were below 30 years of age $(87.6 \%)$.

\section{CONCLUSION}

There is a significant difference in birth weight among age groups ranging from 19-35 years. However, a larger study involving multiple centres will further strengthen this study.
Funding: No funding sources

Conflict of interest: None declared

Ethical approval: The study was approved by the Institutional Ethics Committee

\section{REFERENCES}

1. Luo ZC, Nuyt AM, Delvin E, Audibert F, Girard I, Shatenstein B, et al. Maternal and fetal IGF-I and IGFII levels, fetal growth, and gestational diabetes. J Clin Endocrinol. 2012;97(5):1720-8.

2. Murray PG, Clayton PE. Endocrine control of growth. Am J Med Genet Part C Semin Med Genet. 2013;163(2):76.

3. Forhead AJ, Fowden AL. The hungry fetus? Role of leptin as a nutritional signal before birth. J Physiol. 2009; 15;587(Pt 6):1145.

4. Karakosta P, Chatzi L, Plana E, Margioris A, Castanas E, Kogevinas M. Leptin levels in cord blood and anthropometric measures at birth: a systematic review and meta-analysis. Paediatr Perinat Epidemiol. 2011;25(2):150-63.

5. Kyriakakou M, Malamitisi-Puchner A, Militsi H. Leptin and adiponectin concentrations in intrauterine growth restricted and appropriate for gestational age fetuses, neonates and their mothers. Eur $\mathbf{J}$ Endocrinol. 2008;158(3):343.

6. Mise H, Yura S, Itoh H, Nuama MA, Takemura M, Sagawa $\mathrm{N}$, et al. The relationship between maternal plasma leptin levels and fetal growth restriction. Endo J. 2007:0711120019.

7. Gibbs CM, Wendt A, Peters S, Hogue CJ. The impact of early age at first childbirth on maternal and infant health. Paediatr Perinat Epidemiol. 2012;26:259-84.

8. Kenny LC, Lavender T, McNamee R, O’Neill SM, Mills T, Khashan AS. Advanced maternal age and adverse pregnancy outcome: evidence from a large contemporary cohort. PloS One. 2013;8(2):e56583.

9. Pollack H, Lantz PM, Frohna JG. Maternal smoking and adverse birth outcomes among singletons and twins. Am J Public Health. 2000;90:395.

10. Jaddoe VW, Bakker R, Hofman A, Mackenbach JP, Moll HA, Steegers EA, et al. Moderate alcohol consumption during pregnancy and the risk of low birth weight and preterm birth. The generation R study. Ann Epidemiol. 2007;17:834-40.

11. Blumenshine P, Egerter S, Barclay CJ, Cubbin C, Braveman PA. Socioeconomic disparities in adverse birth outcomes: a systematic review. Am J Prev Med. 2010;39:263-72.

12. East PL, Felice ME. Adolescent pregnancy and parenting: findings from a racially diverse sample. Psychology: 2014:In Press.

Cite this article as: Goel S, Abichandani R.

Correlation of maternal age with birth weight: need to reemphasize. Int J Reprod Contracept Obstet Gynecol 2020;9:184-6. 